\title{
Statyba
}

\section{MULTIDIMENSIONAL DATA ANALYSIS IN CONSTRUCTION INDUSTRY}

\section{A. Fojud}

To cite this article: A. Fojud (2000) MULTIDIMENSIONAL DATA ANALYSIS IN CONSTRUCTION INDUSTRY, Statyba, 6:6, 431-435, DOI: 10.1080/13921525.2000.10531626

To link to this article: https://doi.org/10.1080/13921525.2000.10531626

曲 Published online: 26 Jul 2012.

Submit your article to this journal 2

III Article views: 68 


\title{
MULTIDIMENSIONAL DATA ANALYSIS IN CONSTRUCTION INDUSTRY
}

\author{
A. Fojud \\ Poznan University of Technolog!
}

\section{Introduction}

At the end of the century, when it not the access to information necessary in taking decisions which is a prerequisite for success, but the speed of analysing and processing such information, the significance and scope of usage of multidimensional information analysis has increased greatly. Strategic decisions must be taken quickly, firmly and, at the same time, leaving enough room for the presentation of accurate arguments supporting a given choice. Possibilities of analysing and using information stored in data warehouses have now twofold significance, looking from the standpoint of strategic decisions $[1,2]$. Firstly, fast multidimensional information analysis facilitates the optimisation of decisions, which are to be taken. It is particularly important in the case of decisions being taken in the context of shortage of budget resources, in the framework of the so-called minimum budget economy. Secondly, fast and efficient data analysis quite efficiently supports arguments highlighting the needs, and helps combat the competition with the arsenal of prospective presentation of multidimensional data.

Another important quality of multidimensional analysis is the possibility of obtaining the answer to .. What if..." questions in real time. in the so called ..on linc" mode. Such a possibility of forecasting change and the influence of decisions to be taken involving the object under scruting ficcilitate fast and eflicient assessment of options. In order to fully utilise the possibilities of mulidimensional analysis. He need to use information technology in modelling the real world in such a way that the analysed objects or their parts are represented as multidimensional entities with a reflection in a data base. The database itself, as an information warehouse describing the world we are try- ing to model, must be closely linked to the tools used in multidimensional analysis. The set of tools used in multidimensional analysis, together with the properly designed information warehouse, has been found extremely useful in the design aid systems. A similar arrangement may also be used in building an expert or advisory system, assisted by an appropriate conclusion formulating mechanism which would make the most possibilities presented by the multidimensional analysis performed in real time. Due to the fact that the subject area is vast, the problem under discussion has been narrowed down to the question of designing and maintenance of roads and motorways. Due to the editorial limitations, the subject area will be presented in more detail and discussed in the papers to follow this one shortly. This paper is divided into two parts: the first describes the questions of modelling and multidimensional analysis in view of road design, and the second part touches upon the module structure of building an expert system embracing a mechanism of multidimensional analysis of information. How such a system is built will be shown on the example of a Advisory System used in road network management [3].

\section{Modelling and multidimensional analysis in design}

During the process of numerical modelling. the first element that undergoes analysis is landform (terrain). l.andtom is created on the basis if land surveys (geo)detic measurements) and mapped as a numerical model of land. The clements constituting a numerical model of the land form are the strings of graphic data. ie sets of interrelated points. Each string has its co-ordinates: $x, y$ an ordinate, and the point number. Moreover. each string has an individual name. Such strings are threedimensional information strings, called sub-strings. 
Sub-strings help describe the landform (terrain), defining the characteristic contours, and dispersed picket points. Such a representation, though, is not an accurate representation of the terrain. Having at our disposal a model consisting of $3 \mathrm{D}$ sub-strings representing. for example, the contours of a road, hard shoulders. ditches, and so on. we can put such a model through a process of multidimensional analysis. If such an analysis is performed using a two-stage interpolation (primary and secondary), what we get in effect is a 36-dimension triangulation model. It is a multidimensional analysis of a simple string model with a resulting transformation leading to a triangulation model.

Thanks to such an analysis we obtain an accurate model of the terrain. Another example of multidimensional analysis and the resulting transformation is the analysis of a triangulation model going from the 36dimension form to a 2.5 dimension form. In effect, we obtain a layer type model of land surface, which describes it equally accurately, with a simplified notation in the data warehouse pertinent to the model.

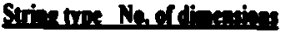

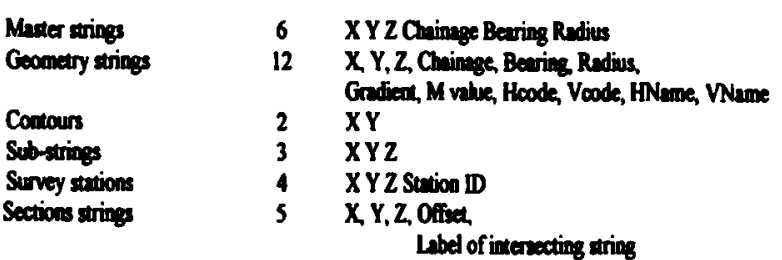

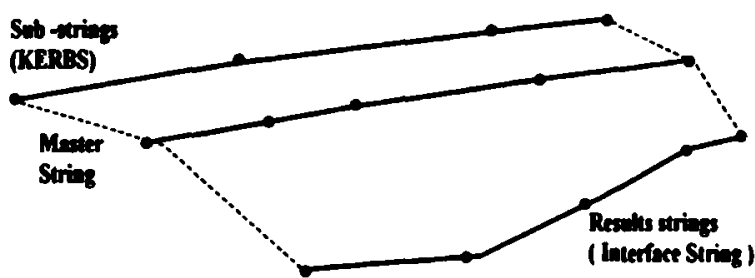

Fig 1. Basic types of strings used in modelling and in multidimensional analỵsis

Since the route axis is one of the most important elements in the process of designing linear objects. it is defined in a very special way by the multidimensional system. A 6-dimensional string. called a Master String, having referential links with a 12-dimensional geometric string generated automatically when the mas- ter string is built defines it. Performing a multidimensional analysis and a geometrical transformation, we can generate the whole body of the road on the basis of the master string.

\section{Triangulation}

- Survey or design models using strings

- Analyses models using a triangular Model Good triangulation result

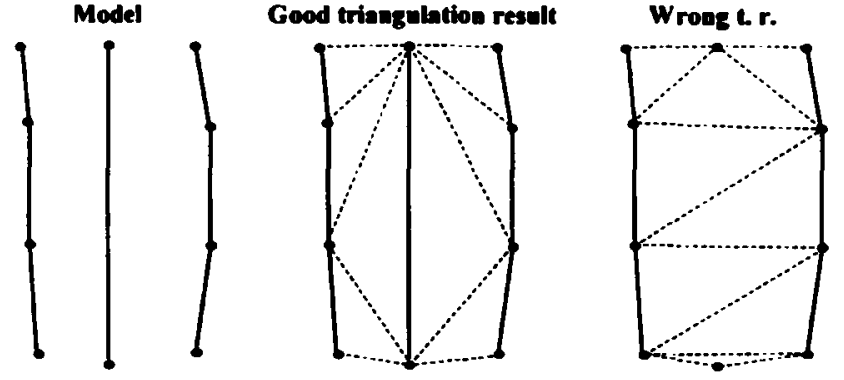

Fig 2. Triangulation - a result of a multidimensional analysis and transformation

Following the analysis of two models, for example, the model of terrain and the model of the designed road body, it is possible to arrive at a string defining the line where those models come across. It is particularly useful in modelling slopes. Such an analysis is performed in a forward and backward option, defining the linking parameters in the two options. In effect, we obtain a 5-dimensional resulting string, called the interface string.

It is possible to use a thorough multidimensional analysis to test a single string model, in order to, for example, arrive at cross or longitudinal sections of the terrain only.

The six dimensions stored for each point on a master string are :

$X, Y, z$, Chainage, Baning, Radius

- Contains points at

- Regular chainage interval

- Horizontal tangent points

- Vertucal tangent points

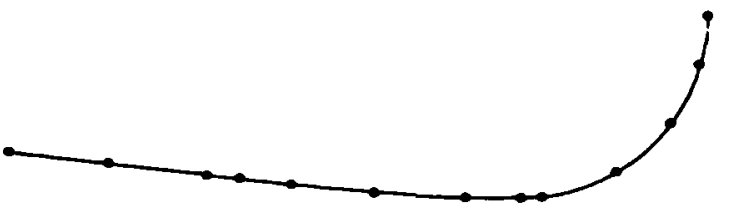

Fig 3. Multidimensional MASTER STRINGS 
- The twelve dimensions stored for each point on a geometry string are: $X, Y, Z$, Chainage, Bearing, Radius, Gradient, Mr value, Hcode, Vcode, HName, VName

- Contains points at

- primary geometric points only

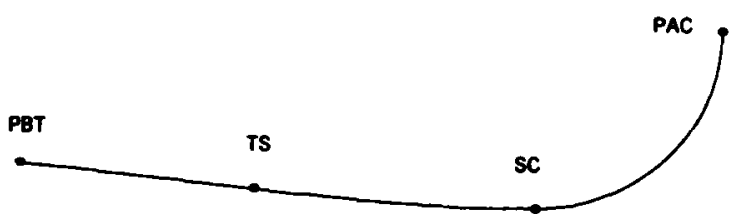

Fig 4. Multidimensional GEOMETRIC STRINGS

Or else, a number of models together arriving at. for example, a designed road body and the terrain, and obtaining the results regarding volume of area of future earth or surface work.

Therefore, a multidimensional model is a good and reliable tool, which can be used in modelling and reviewing design options of different kinds of linear and three-dimensional structures. Summing up, it is possible to adopt the procedure described above to assist and facilitate modelling and multidimensional analysis in design. Using geometric strings, we can give a representation of contours of an existing road, hard shoulder, ditch, pavement, buildings, and so on.

Another element contributing to the information about the modelled fragment of the real world is a string of dispersed points. Such a string may represent a set of point type elements classified into one category, such as: characteristic features land, or trees, lamp-posts, and so on.

This type of string. in contrast to the previous one. does not have obvious geometric links between the points and. therefore. the system analyses it as a set of dispersed points. not accounting for the links between points as contours.

The terrain represented by means of those two types of strings forms the so-called primitive numerical model of the land formation. It is a simplitied cersion of the terrain becausc the system. during the analysis. may represent an untrue reflection of reality due to. for example. little density of points and contours in the fragment of terrain under scrutiny.

In order to support the person responsible for technical drawings. and try to represent more accurately the numerical model of the terrain, another type of string has been introduced. This string is generated on the basis of the analysis of a primitive model of the terrain.

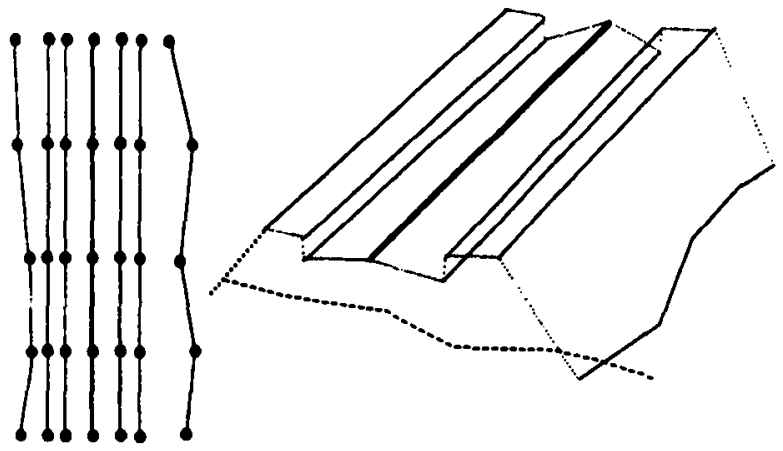

Fig 5. A model of the road body under design together with the terrain model

The string in such a shape has 36 dimensions and represents a model of triangulation of the terrain, ie the representation of the terrain by means of triangular planes of the same inclination.

The basic benefit of the 36-dimensional triangulation string is an accurate representation of the terrain, and its drawback is a huge memory demand. In order to minimise the trouble of having to provide so much information for each individual point on the string, the triangulation string itself is regarded as a transition analysis tool and a basis for generating a string which unequivocally describes a model of the terrain, and has a benefit of being 2,5-dimensional. The reason is that it only has $x, y, z$ co-ordinates, and an ordinate for a heading of each series of points constituting a string.

Another characteristic type of information is a string representing a section of the existing terrain through the modelled body, called an interface. It is a 5-dimensional string. generated automatically as a result of the analysis of the numerical model of the terrain and of the body (Fig 1 ).

- Points calculated from trangle edges and faces

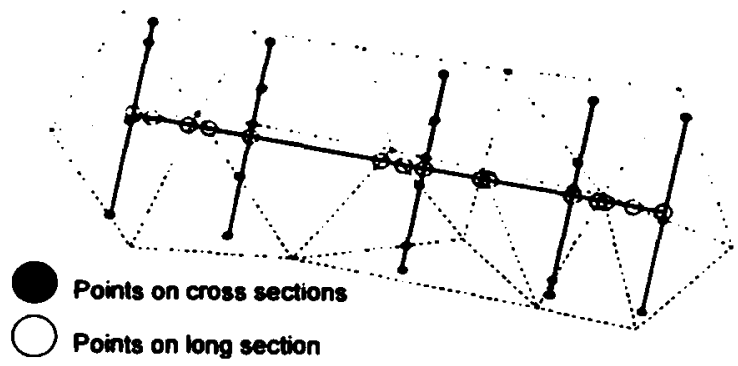

Fig 6. Sections through triangulation 


\section{Cross sections..}

- Cross sections stored as individual strings

- Onty initial character given, not full string name

- for example, 'D' for design, 'E' for existing

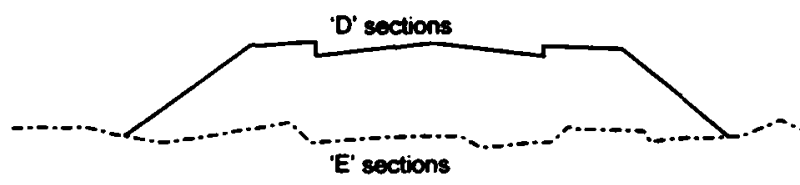

Fig 7. Cross and longitudinal sections resulting from multidimensional analysis of string model

Yet another element occurring in a technical design of a road is the road axis. This element is modelled numerically, often as a 6-dimensional element of the road that, apart from the first four dimensions. namely: point number, $x, y$, and $z$, contains information about the azimuth, and about picketage. On the basis of such a string, pending an appropriate analysis, it is possible to generate simple strings and add to the designed body, for example, of a road. Using the elements, so expanded in dimensions, it is possible to make clear designs of various linear objects. A multidimensional character of such a design facilitates fast and accurate analysis of a design and becomes a tool to generate a number of optional solutions. The type of modelling and multidimensional analysis presented in Part 1 has been used in many new generation CAD systems, and the MX family products based on the MOSS system may serve as a good example of this statement.

\section{Multidimensional analysis in property management}

Another example of utilising multidimensional data analysis in construction industry is applying it to road maintenance. The awareness of the necessity of planning the desclopment and maintenance of the network of roads. defining strategic targets and methexds wo reach those targets is a key ability of staff responsible for road network maintenance. Fast development of information technology has resulted in the advisory systems using multidimensional informational analysis in data warehouses becoming the basic tool in property management.

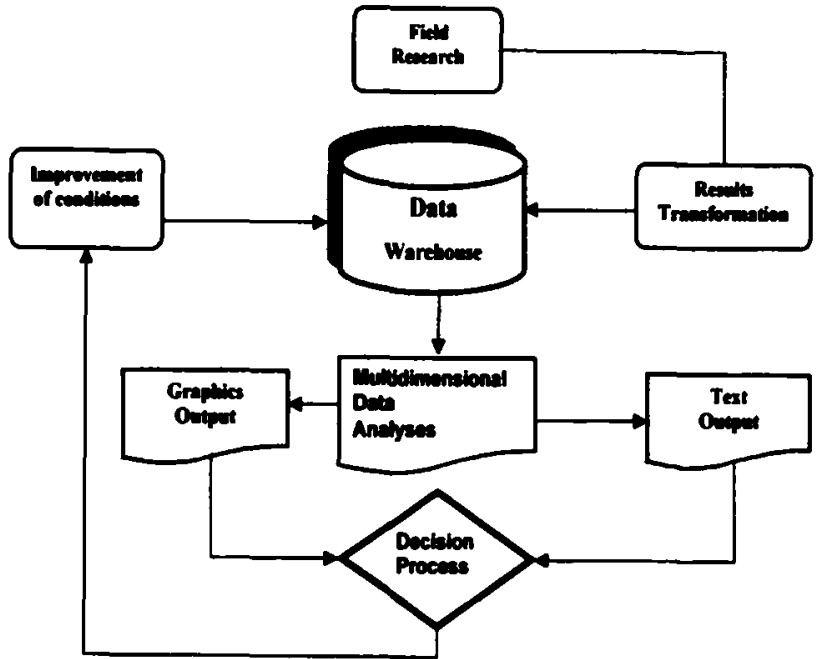

Fig 8. An example of a pattern of an advisory system using a multidimensional analysis module

Proper organisation in data warehouses facilitates fast, multidimensional analysis of information and its prospective presentation. Information is made available and is analysed in accordance with the user's level of accessibility. The authorisation level is a consequence of the role a user of the system plays in the decisionmaking process, in other words, is a consequence of the user's competence.

The multidimensional character of the advisory system is not only reflected in the way information is analysed, but also in its multidimensional presentation.

In presentation, multidimensional systems use both information displayed as text and graphics. A general pattern of an advisory system, which uses this type of analysis, is shown in Fig 8.

As a result, the advisory system, thanks to the multidimensional analysis of historical information and current data, facilitates the presentation of the real or prospective state of the managed property. depending on the needs of a person taking a decision. The system enables a spatial presentation of information. as illustrated in Fig 9.

A spatial set of information consisting of time. condition. and types of elements facilitates analysis within a given range. The ...* type of spatial perspective presents the result of the analysis. thanks to which we obtain information regarding all objects within a network of streets in a selected time span. Such an analysis may provide an accurate answer to the question of the state of road network over the time that is 
interesting for the user. Adding other dimensions. such as a set of maintenance decisions, we can obtain simulations illustrating the effect of the decisions which have been taken about the state of managed property.

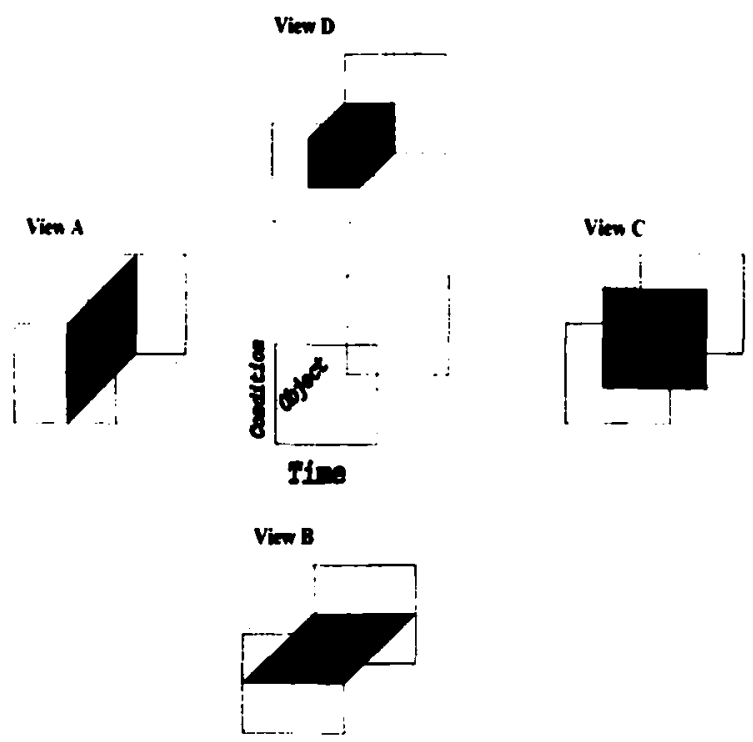

Fig 9. Selected examples illustrating multidimensional features of an advisory system

The „B" perspective presents the result of the analysis which provided an answer to the question as to which elements still remain in the state assumed for them in a chosen time span pointing, for example, at the elements which have not become degraded since the previous year.

The "C" perspective illustrates a possibility of obtaining an answer to the question of the state represented by all the elements categorised as one type. Such an analysis facilitates the verification of the degradation of road surface, for example. from SMA on expressways.

Another interesting example of spatial analysis is the analysis of selected elements which. within the assumed rime span. Would reach the assumed qualitication. for example .poor” - perspectice ...". Haw ing a properly designed datal warehouse related to the mechalnism of multidimensional analỵsis al our disposial. Wo could multiply dimensions and categories of the analysis. In effect. We could obtain last reporting on the existing or forecast state of the network. If we state tasks related to the dimensions we are interested in. and state masks the user is interested in, the multidimensional analysis can provide quite accurate answers to fairly complex problems.
These categories of systems, presented in a sketchy way, have found its way to engineer's everyday practice. Such advisory systems using a multidimensional analysis tool linked with a properly designed data warehouse can be extended by an addition of a multidimensional economic analysis module. The author will present the subject in forthcoming work. The discussed systems facilitate forecasting. and not only with respect to technical condition of the network. but also with respect to the risk related to the decisions which have been taken, and help optimise the distribution of resources necessary to maintain the road network in good technical condition.

\section{References}

1. Opis techniczny możliwości systemu MOSS, PC++ Software Studio, Materiały niepublikowana, Gdańsk, 1997.

2. Ullman Principles of Database and Knowledge-Base Systems, Vols 1 and 2, Computer Science Press. Rockville, MD 1988.

3. A. Fojud. Digital Method in design project on example Motorway A4 Computer Method in Civil Engineering. Warszawa, 1997.

Iteikta 20001104

\section{DAUGIAMAČIU DUOMENU ANALIZE STATYBOS VEIKLOJE}

\section{A. Fojud}

\section{Santrauka}

Siuo metu statyboje vis placiau diegiamos naujausios technologijos, kartu kiekvienoje pastato ar statinio statybos stadijoje atsiranda vis daugiau projektiniu sprendimu. Dél to kyla ivairiu problemu, susijusiu su sprendimu priemimo proceso optimizavimu bei tinkamy argumentu, priimant konkrečius sprendimus inžineriniame darbe. pateikimu. Todèl inžinerinèje praktikojc labai svarbi sisteminè daugiamatès informacijos analizć. Straipsnyjc patcikiama daugiamačiu duomeny analizès statybos veikloje galimybių studija ir pabréżiama didćjanti daugiamates informacijos analizès svarba kasdieniame inżinicriaus darbc. taip pat valdant nuosasybę. Aprašytos projektavimo. pagristo daugiamaciais duomenimis. galimybes ir tokiu. projektuose naudojamu duomenu. analize. Antrojoje straipsnio dalyjo patcikiama daugiamats analizes taikymo sprendimy priemimo sistemesce. skirtoxc zmonems. priimanticms nuosilrythes valdṣmo sprendomus, nauding̣umo ir sartmos analize.

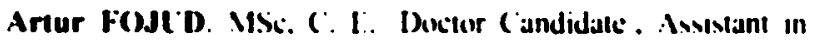
Division of Construction Lnginczrong and Management. Poznan University of Technolugy: Structural Institute of Enginecring. Piotrowo 5. 601065.5 Poznan. Poland.

E-mail: Fojuda sol.put.poznan.pl

Rescarch interests: evolutionary programming and genetics algorithms, hybrid advisory systems, databases, scheduling. road management, road design, road conditions and transportation problems. 